\title{
PENGGUNAAN MEDIA PEMBELAJARAN BERBASIS ALAM \\ UNTUK PENGEMBANGAN KOGNITIF ANAK USIA 5-6 TAHUN
}

\section{THE USE OF NATURE-BASED LEARNING MEDIA \\ TO DEVELOP THE COGNITIVE ABILITY OF CHILDREN AGED 5-6 YEARS}

\author{
Susmiyati Jiwaningrum, Yoyon Suryono \\ SKB Kabupaten Magelang, Universitas Negeri Yogyakarta \\ miyapoenya@yahoo.com,yoyonsuryono@yahoo.com
}

\begin{abstract}
Abstrak
Penelitian ini bertujuan untuk mengungkap: (1) kemampuan kognitif anak, (2) penggunaan media pembelajaran berbasis alam dan, (3) dampak penggunaan media pembelajaran berbasis alam terhadap pengembangan kemampuan kognitif anak. Penelitian ini merupakan penelitian tindakan kelas dengan dua siklus terdiri atas perencanaan, tindakan, observasi, dan refleksi. Subjek penelitian ini adalah anak, pendidik dan pengelola. Pengumpulan data dilakukan melalui pengamatan, wawancara, catatan lapangan, dan studi dokumentasi. Teknik analisis data yang digunakan adalah reduksi data, mendeskripsikan data, dan membuat kesimpulan. Hasil penelitian menunjukkan kemampuan kognitif anak sebelum tindakan masih dalam kategori mulai berkembang; hasil penelitian siklus II menunjukkan hasil yang lebih baik dari siklus I; penggunaan media pembelajaran berbasis alam mempunyai dampak sangat baik ditunjukkan dengan kemampuan kognitif anak yang mengalami perkembangan yang sangat baik dibandingkan sebelum tindakan.
\end{abstract}

Kata Kunci: media alam, kemampuan kognitif, pendidikan anak usia dini.

\begin{abstract}
This study aims to reveal: (1) the cognitive ability of children, (2) the use of nature-based learning media, and (3) the impact of the use of nature-based learning media on the development of the cognitive ability of the children. This was a classroom action research study with two cycles consisted of planning, action, observation, and reflection. The research subjects are children, teachers, and managerial personnel. The data were collected through observations, interviews, field notes, and documentation study. The data analysis technique consisted of data reduction, data description, and conclusion drawing. Based on the results of the study, the following conclusions can be drawn the cognitive ability of the children in the group of before the actions was growth; the results in Cycle II were better than those in Cycle I; the use of the naturebased learning media has very good impacts; this was indicated by the cognitive ability of the children which developed better than that before the actions.
\end{abstract}

Keywords: nature media, cognitive ability, early childhood education. 


\section{PENDAHULUAN}

Menurut Undang-undang Nomor 20 Tahun 2003 tentang Sistem Pendidikan Nasional, pendidikan adalah usaha sadar dan terencana untuk mewujudkan suasana belajar dan proses pembelajaran agar peserta didik secara aktif mengembangkan potensi dirinya untuk memiliki kekuatan spiritual keagamaan, pengendalian diri, kepribadian, kecerdasan, akhlak mulia, serta keterampilan yang diperlukan dirinya dan masyarakat, bangsa, dan negara.

Pendidikan anak usia dini (PAUD) berperan penting dalam tumbuh kembang anak, karena dalam kegiatannya menekankan pengenalan pendidikan baik yang memicu perkembangan berbagai sisi dan kebutuhan individu anak. Masa emas (golden age) perkembangan anak terjadi pada usia dini, dimana $80 \%$ perkembangan kognitif telah dicapai pada masa ini. Kognitif anak merupakan pemrosesan informasi tentang lingkungan yang diapresiasi melalui panca indra, dengan memanfaatkan lingkungan alam sekitar sebagai media pembelajaran yang dapat mengembangkan kognitif anak.

Proses pembelajaran PAUD memerlukan penggunaan media pembelajaran agar pembelajaran dapat mencapai hasil belajar yang lebih baik. Pada saat ini anak usia dini lebih banyak belajar di ruangan tanpa menikmati alam sekitar. Memanfaatkan alam sekitar sebagai media pembelajaran PAUD pada dasarnya adalah mengembangkan pengetahuan umum dan sains anak dengan menjelaskan konsep-konsep tertentu secara alami yang sederhana dalam kehidupan sehari-hari seperti warna secara nyata yang ada pada lingkungan alam sekitar, konsep air mengalir dari tempat yang tinggi ke rendah. Penggunaan media berbasis alam ini akan membantu mendekatkan jarak pemahaman kognitif anak tentang suatu konsep dan kegiatan yang dipelajari dalam pembelajaran.

Dalam penggunaan media pembelajaran alam, pendidik diharapkan memiliki pengetahuan dalam menggunakan media pembelajaran, sehingga mampu memanfaatkan secara optimal media pembelajaran alam yang tersedia. Pendidik akan ber- pikir secara kreatif untuk mengembangkan kemampuan kognitif anak melalui media pembelajaran berbasis alam ini sehingga kegiatan pembelajaran diharapkan dapat efektif. Namun, belum banyak lembaga pendidik dan penyelenggara PAUD yang memanfaatkan lingkungan alam sebagai media pembelajaran untuk mengembangkan kemampuan anak dalam berbagai aspek terutama dalam kemampuan kognitif.

Lingkup perkembangan kognitif untuk anak usia empat sampai enam tahun yang terdapat dalam Peraturan Menteri Pendidikan Nasional No 58 Tahun 2009 tentang standar pendidikan anak usia dini, terdiri atas: (1) pengetahuan umum dan sains, (2) konsep bentuk, warna, ukuran, dan pola, (3) konsep bilangan, lambang bilangan dan huruf. Perkembangan kognitif itulah yang diharapkan tercapai dalam pembelajaran di pendidikan anak usia dini.

Hasil penelitian terdahulu yang telah dilakukan dalam lingkup perkembangan kognitif anak usia dini menyebutkan bahwa penggunaan media pembelajaran dengan memanfaatkan media alam masih perlu ditingkatkan agar penggunaan media pembelajaran berbasis alam lebih optimal. Perkembangan kognitif anak usia dini melalui pembelajaran sains berbasis lingkungan sekitar lebih menekankan pembelajaran dengan memanfaatkan sarana dan prasarana yang ada di alam akan lebih bermakna bagi anak, untuk itu diperlukan kreativitas dari pendidik dalam melaksanakan pembelajaran untuk mengembangkan kognitif anak.

Media pembelajaran berbasis alam telah digunakan di PAUD Pandan Wangi, tetapi belum optimal, pembelajaran masih lebih banyak menggunakan media pembelajaran buatan (APE) buatan pabrik, sehingga penggunaan media pembelajaran berbasis alam masih terbatas, sehingga tingkat pencapaian perkembangan anak terutama perkembangan kognitif sesuai permendiknas No 58 Tahun 2009 yang diinginkan belum tercapai.

Tingkat pencapaian kemampuan kognitif masih ada anak yang mempunyai kemampuan kognitif belum sesuai dengan capaian yang dikehendaki, yaitu minimal 
anak mempunyai kemampuan kognitif berkembang sesuai harapan (BSH). Kemampuan kognitif dapat diukur dari ketercapaian indikator kemampuan kognitif yang diterapkan dalam pembelajaran.

Permasalahan yang terkait dengan perkembangan kognitif dalam penelitian ini adalah: (1) Bagaimana kondisi objektif kemampuan kognitif anak?; (2) Bagaimana penggunaan media pembelajaran berbasis alam untuk mengembangkan kemampuan kognitif anak?; dan (3) Bagaimana dampak penggunaan media pembelajaran berbasis alam pada kemampuan kognitif anak di PAUD Pandan Wangi?

Kelemahan-kelemahan anak pada PAUD Pandan Wangi dalam mencapai indikator perkembangan kemampuan kognitif yang diharapkan harus segera diatasi agar setiap indikator yang ditetapkan dapat tercapai. Salah satu cara yang dapat dilakukan adalah menerapkan pembelajaran melalui penggunaan media yang tepat, menarik, efektif agar tujuan pembelajaran yang dilaksanakan dapat tercapai, terutama untuk mengembangkan kemampuan kognitif.

Penelitian ini bertujuan untuk mengetahui (1) kemampuan kognitif anak di PAUD Pandan Wangi; (2) penggunaan media pembelajaran berbasis alam dalam mengembangkan kemampuan kognitif anak usia dini yang digunakan di PAUD Pandan Wangi; (3) dampak penggunaan media pembelajaran berbasis alam dalam mengembangkan kemampuan kognitif anak usia dini yang digunakan di PAUD Pandan Wangi.

Dari penelitian ini diharapkan lembaga PAUD dapat meningkatkan kualitas pembelajaran yang berkaitan dengan penggunaan media pembelajaran berbasis alam untuk mengembangkan kemampuan kognitif anak usia dini. Manfaat penelitian secara akademik memberikan inovasi dan kreativitas dalam penggunaan media pembelajaran untuk pengembangan kemampuan anak usia dini sesuai yang diharapkan.

Media pembelajaran yang tepat, menarik dan efektif digunakan dalam pembelajaran untuk mengembangkan kognitif anak adalah menggunakan media pembelajaran berbasis alam. Media pembelajaran berbasis alam mudah diperoleh di sekitar lingkungan PAUD Pandan Wangi, dengan memanfaatkan lingkungan sekitar yang berwujud; sawah, hewan, tanaman, air, tanah, pasir, batu-batuan, flora dan fauna, lumpur, hujan, matahari, rawa serta kebunkebun yang dekat dengan lingkungan sekolah.

Dalam Depdiknas (2008:3) landasan filosofis tentang pendidikan anak usia dini berbasis alam yang dikemukakan oleh Rousseau yaitu: (1) pendidikan harus mengembangkan kemampuan-kemampuan alami atau bakat anak dan (2) pendidikan yang berlangsung dalam alam. Filosofis dasar yang berhubungan dengan pembelajaran yang berbasis alam adalah pandangan bahwa kegiatan pendidikan (sekolah atau kurikulum) harus dapat membantu anak mengembangkan berbagai potensi perkembangan yang dipergunakan untuk beradaptasi secara kreatif dengan lingkungan alam.

Kegiatan pembelajaran yang berbasis pada lingkungan alam akan membantu anak usia dini mengelaborasi dan mengeksplorasi lingkungan alam sebagai media belajar dan menstimulus atau merangsang perkembangan kognitif anak sesuai dengan tahap perkembangan anak. Hal ini sejalan dengan pendapat Nielsen (2008, p.3) yang mengemukakan bahwa pembelajaran yang dilakukan pada anak usia dini dapat menambah pengetahuan dan kualitas pengalaman mereka.

Dalam melaksanakan kegiatan belajar dan bermain, agar anak usia dini mendapatkan kecerdasan yang optimal, kegiatan bermain hendaknya dilaksanakan dengan memperhatikan banyak hal. Hal-hal yang harus diperhatikan sesuai pendapat Sujiono (2009, p.62) antara lain anak hendaknya diberi kesempatan luas dalam pembelajaran untuk mengembangkan potensinya, pembelajaran yang dilakukan hendaknya anak diberi kesempatan untuk mengintegrasikan pengetahuan deklaratif yang telah dipelajari dengan pengetahuan prosedural untuk melakukan tugas-tugas dan memecahkan masalah, dan proses belajar tidak sekedar bersifat transferal tetapi lebih merupakan kokonstruksi. 
Menurut Segal, et al (2012, p.104) pengalaman sebelumnya membentuk pengetahuan dan menyimpannya di otak, secara bersamaan akan terbentuk pula pengetahuan baru dan akan selalu dikembangkan berdasarkan fungsi yang ada dan yang telah dikembangkan sebelumnya. Pengetahuan tersebut akan digunakan untuk mengembangkan diri untuk memperoleh pengetahuan yang lebih tinggi seperti kemampuan berbicara, membaca, dan menulis.

Keterlibatan dan interaksi anak dengan lingkungan sekitar sangat penting dalam perkembangan kecerdasan anak. Seperti juga disampaikan oleh Morrison (2008, p.72), "lewat interaksi dengan lingkungan, anak-anak mengorganisir sensasi dan pengalaman dan otak mereka berkembang. Oleh karena itu, jelas kualitas lingkungan dan sifat dasar pengalaman anak berperan penting dalam perkembangan kecerdasan".

Interaksi antara individu dan lingkungannya dapat dilakukan melalui proses pembelajaran di pendidikan anak usia dini dengan memanfaatkan lingkungan alam di sekitarnya agar terjadi proses pembelajaran yang melatih proses berpikir anak. Hal ini sesuai dengan pendapat Morrison (2012, p.72) yang mengemukan bahwa dengan aktivitas dan interaksi dengan orang lain maka anak-anak akan terus menerus mengorganisir, menyusun, dan menyusun kembali pengalaman-pengalaman yang telah ada, sehingga anak-anak dapat membangun kecerdasan mereka sendiri.

Media pembelajaran yang bersumber dari lingkungan sekitar dapat dijadikan sebagai pengalaman langsung yang dapat meningkatkan hasil belajar seseorang. Hal ini sesuai dengan pendapat Arsyad (2011, p.10) menyatakan bahwa "pengalaman langsung akan memberikan kesan paling utuh dan paling bermakna mengenai informasi dan gagasan yang terkandung dalam pengalaman itu, oleh karena ia melibatkan indera penglihatan, pendengaran, perasaan, penciuman, dan peraba". Menggunakan media pembelajaran berbasis lingkungan dapat mempermudah pengalaman belajar anak usia dini. Dalam pembelajaran anak usia dini harus dibatasi pada jenis materi tertentu yang sesuai dengan perkembangan anak, karena kemampuan untuk belajar tentang ide tertentu dibatasi oleh pikiran dari setiap individu tersebut. pengalaman belajar dibangun di seputar struktur kognitif pembelajar. Dalam melaksanakan pembelajaran anak-anak sebagai pembelajar yang berusia sama dan dari budaya yang sama cenderung memiliki struktur kognitif yang sama pula. Akan tetapi dimungkinkan juga akan terjadi perbedaan, oleh karena itu perlu adanya materi yang sesuai agar dapat melakukan modifikasi dalam struktur kognitifnya melalui dua cara beradaptasi yaitu asimilasi dan akomodasi.

Menurut Hergenhahn \& Olson (1997, p.283) "the process of responding to the environment in accordance with one's cognitive structure is called assimilation". Hal itu berarti terjadi penyesuaian antara struktur kognitif dengan lingkungan pada saat proses asimilasi.

Semakin banyak pengalaman, maka akan semakin berkembang pula struktur kognitifnya. Setelah struktur kognitif meluas mereka akan akan merespon situasi yang lebih kompleks.

Perkembangan kognitif anak usia dini pada setiap tahapannya mempunyai karakteristik yang berbeda-beda. Anak usia dini memiliki pengalaman yang sangat berbeda dibandingkan dengan anak-anak atau orang dewasa tentang alam. Hasil belajar yang didapatkan dari anak usia dini dipengaruhi oleh pengetahuan dan pengalamannya. Hal ini sesuai pendapat Galotti (2004, p.469) menyatakan "instead Piaget believed children construct their own mental structures, the building blocks of cognition and intelegence, through a constant and active series of interactions with their environment". Piaget percaya bahwa anak-anak mengkonstruksi struktur mental mereka sendiri terbangun dalam kognisi mereka dan secara aktif merupakan hasil interaksi mereka dengan lingkungannya.

Berikut adalah tabel tingkat pencapaian perkembangan kognitif anak usia 5-6 tahun sesuai permendiknas No 58 Tahun 2009 yang dijadikan sebagai indikator pembelajaran. 
Tabel 1. Tingkat Pencapaian Perkembangan Kognitif Anak Usia 5-6 tahun

\begin{tabular}{|c|c|}
\hline Lingkup Perkembangan & Tingkat Pencapaian Perkembangan Usia 5-6 Tahun \\
\hline $\begin{array}{l}\text { Kognitif } \\
\text { A. Pengetahuan Umum dan Sains }\end{array}$ & $\begin{array}{l}\text { Menunjukkan aktivitas yang bersifat eksploratif dan } \\
\text { menyelidik. }\end{array}$ \\
\hline & 2. Sebab akibat tentang lingkungannya. \\
\hline \multirow{5}{*}{$\begin{array}{l}\text { B. Konsep Bentuk, Warna, Ukuran } \\
\text { dan Pola }\end{array}$} & 3. Menunjukkan inisiatif dalam memilih tema permainan. \\
\hline & $\begin{array}{l}\text { 1. Mengenal perbedaan berdasarkan ukuran "lebih dari", "kurang } \\
\text { dari", dan "paling/ter". }\end{array}$ \\
\hline & $\begin{array}{l}\text { 2. Mengklasifikasikan benda berdasarkan warna, bentuk, dan } \\
\text { ukuran ( } 3 \text { variasi). }\end{array}$ \\
\hline & 3. Mengenal pola ABCD-ABCD. \\
\hline & $\begin{array}{l}\text { 4. Mengurutkan benda berdasarkan ukuran dari paling kecil ke } \\
\text { paling besar atau sebaliknya. }\end{array}$ \\
\hline $\begin{array}{l}\text { C. Konsep bilangan, lambang } \\
\text { bilangan dan huruf }\end{array}$ & 1. Menyebutkan lambang bilangan 1-10 \\
\hline
\end{tabular}

\section{METODE}

Penelitian ini merupakan penelitian tindakan kelas dengan pendekatan kualitatif. Pendekatan lebih menekankan pada aspek proses daripada hanya sekedar hasil, dan penelitian kualitatif memiliki data-data yang diperoleh melalui pengamatan (observasi), hasil wawancara, studi dokumen dan catatan lapangan yang dituangkan dalam bentuk kata-kata (deskriptif). Sejalan dengan pendapat tersebut maka penelitian ini bertujuan untuk mendeskripsikan proses baik proses pembelajaran yang dilakukan oleh pendidik maupun anak usia dini menggunakan media pembelajaran berbasis alam.

Penelitian tindakan kelas ini dilaku-

kan secara kolaboratif antara pengelola, pendidik dan peneliti. Sesuai dengan metode penelitian yang dipilih, penelitian yang akan dilakukan dimaksudkan untuk meningkatkan kualitas pembelajaran dalam memfasilitasi perkembangan anak khususnya dalam aspek perkembangan kognitif melalui penggunaan media pembelajaran berbasis alam Manfaat dari penelitian tindakan kelas untuk membantu pendidik dalam mengatasi masalah mengembangkan kognitif anak melalui media pembelajaran berbasis alam.

Penelitian dilaksanakan di PAUD Pandan Wangi Secang Magelang dengan waktu penelitian dimulai pada bulan Februari sampai dengan bulan Mei 2013. Dalam penelitian ini yang dijadikan subjek penelitian adalah semua komponen yang terlibat dalam kegiatan pembelajaran anak usia dini pada kelompok Matahari 2 di PAUD Pandan Wangi, yaitu anak, pendidik, pengelola. Jumlah anak yang menjadi subjek 10 orang, pendidik 1 orang dan pengelola 1 orang.

Penelitian ini merupakan penelitian tindakan kelas dengan menggunakan siklus I dan siklus II yang didahului prasiklus. Dalam setiap siklus dilaksanakan kegiatan perencanaan,pelaksanaan/tindakan, pengamatan dan refleksi.

Teknik dan alat pengumpulan data yang digunakan dalam penelitian ini didasarkan atas metode yang dilaksanakan. Teknik pengumpulan data yang dilakukan antara lain: pengamatan, wawancara, catatan lapangan, studi dokumentasi.

Pengamatan yang dilakukan adalah pengamatan langsung terhadap proses pembelajaran menggunakan media berbasis alam untuk mengembangkan kognitif anak usia dini yang meliputi aktivitas anak, suasana belajar dan bermain, kondisi lingkungan, dan sejauhmana penggunaan media pembelajaran berbasis alam untuk mengembangkan kognitif anak usia dini.

Wawancara digunakan untuk menggali data secara mendalam terhadap kebermaknaan hasil penggunaan media pembelajaran berbasis alam dalam mengembangkan kognitif anak menurut pendidik sebagai mitra peneliti dan mengetahui kendalakendala selama pelaksanaan pembelajaran.

Catatan lapangan dibuat peneliti untuk menganalisis penggunaan media pembelajaran berbasis alam untuk mengem- 
bangkan kognitif anak usia dini dan merefleksikan tindakan yang telah dilakukan peneliti, apabila tidak mencapai target perlu dilakukan tindakan berikutnya.

Dokumen yang digunakan dalam penelitian ini adalah Rencana Kegiatan Harian (RKH) dan skenario pembelajaran yang telah dilaksanakan, data kemampuan kognitif anak sebelum penerapan tindakan, rekapitulasi pencapaian perkembangan kognitif anak dalam setiap siklus serta portofolio anak.

Teknik analisis data yang digunakan adalah analisis data kualitatif. Data yang diperoleh dianalisis dalam bentuk deskriptif. Analisis data diperlukan sesuai dengan berbagai bentuk jenis data yang diperolehnya. Tahapan analisis data yang dilakukan, yaitu: reduksi data, mendeskripsikan data dan membuat kesimpulan.

Data yang diperoleh dari lapangan berupa laporan, selanjutnya direduksi, dirangkum, dipilih hal-hal yang pokok, difokuskan pada hal-hal yang penting, diberi susunan yang lebih sistematis, sehingga lebih mudah diolah/dikendalikan dan dikelompokkan berdasarkan katagori permasalahan yang diteliti. Mendeskripsikan data dapat dalam dalam bentuk deskripsi yang menyeluruh pada setiap indikator pencapaian pengembangan kognitif anak yang telah ditetapkan sesuai dengan tahapan perkembangannya.

Kegiatan penyimpulan dalam bentuk pernyataan atau formula singkat berdasarkan paparan atau deskripsi yang telah dibuat. Pengambilan kesimpulan dari berbagai data yang telah dipilah dan disajikan diinterpretasikan atau dideskripsikan berdasarkan teori perkembangan kognitif anak usia dini yang disesuaikan dengan hasil temuan di lapangan. Hasil dari interpretasi atau deskripsi yang dilakukan kemudian disajikan sebagai acuan untuk melaksanakan siklus berikutnya.

Agar kesimpulan yang dibuat tidak kabur dan rancu, maka perlu dilakukan validasi melalui cara: Member Check, triangulasi Audit Trail, dan Expert Opinion.

\section{HASIL DAN PEMBAHASAN}

\section{Kemampuan Kognitif Anak Sebelum \\ Penggunaan Media Pembelajaran Berbasis Alam (Kegiatan Pra Siklus)}

Sesuai dengan hasil pra siklus yang dilakukan terhadap Kelompok Matahari 2 PAUD Pandan Wangi pada dasarnya tingkat pencapaian perkembangan kognitif anak usia $5-\leq 6$ tahun sudah mulai berkembang (MB), tetapi secara keseluruhan tingkat pencapaian perkembangan kognitif anak belum optimal atau belum berkembang Sangat Baik (BSB). Kegiatan pembelajaran yang dilaksanakan di Kelompok Matahari 2 dari hasil observasi dan studi dokumen Rencana Kegiatan Harian (RKH) yang dilakukan masih banyak berorientasi atau berpusat pada pendidik dan pendidik kesulitan memilih media alam yang digunakan dalam pembelajaran

Hasil observasi kemampuan kognitif anak sebelum diberi tindakan (Pra Siklus) dapat dilihat pada Gambar 1.

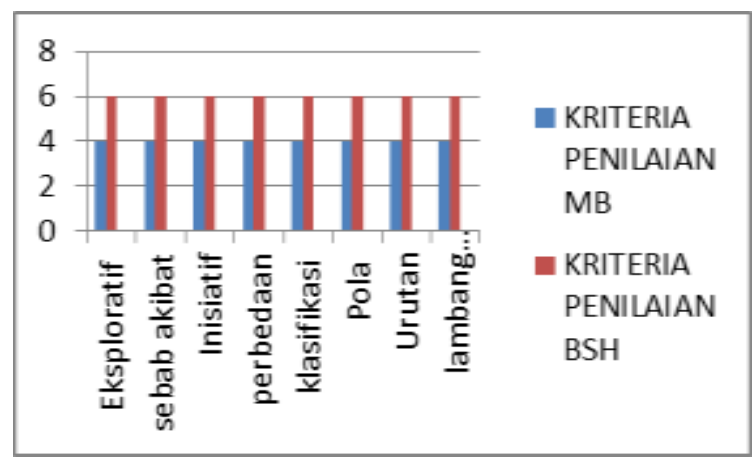

Gambar 1. Hasil Observasi Kemampuan

Kognitif Anak Kelompok Matahari 2

Sebelum Diberi Tindakan (Pra Siklus)

Berdasarkan gambar 1 dapat disimpulkan bahwa kemampuan kognitif pada anak Kelompok Matahari 2 di PAUD Pandan Wangi belum semuanya berkembang optimal. Data tersebut menunjukkan kemampuan kognitif sesuai tahapan perkembangan anak usia dini usia $5-\leq 6$ masih ada yang berkategori mulai berkembang, anak baru mampu melakukan beberapa kegiatan pembelajaran khususnya pembelajaran yang mengembangkan aspek kognitif dan masih memerlukan stimulasi untuk mengembangkan aspek kognitif lebih lanjut. Oleh karena itu perlu dilakukan perbaikan dalam proses 
pembelajaran untuk mengembangkan aspek kognitif yang lebih menarik, kreatif dan inovatif, salah satunya yaitu dengan penggunaan media pembelajaran berbasis alam.

\section{Pelaksanaan Penggunaan Media Pem- belajaran Berbasis Alam}

Pelaksanaan tindakan penelitian melalui penggunaan media pembelajaran berbasis alam dilakukan secara kolaboratif antara peneliti dengan pendidik kelompok Matahari 2 sebagai pengajar. Peneliti dan pendidik bekerja sama saling membantu mulai dari pada perencanaan sampai refleksi, sehingga secara tidak langsung kegiatan penelitian dapat terkontrol dengan baik serta untuk menjaga kevalidan hasil penelitian yang dilaksanakan. Hal ini sesuai dengan pendapat Arifin (2012, p.106) "kolaborasi tim peneliti dalam PTK harus menunjukkan suatu sistem, yaitu tim peneliti mempunyai kedudukan, peran dan tanggung jawab yang sama, saling membutuhkan, dan saling melengkapi untuk mencapai tujuan".

\section{Hasil Penelitian Siklus I}

Pelaksanaan tindakan penggunaan media pembelajaran berbasis alam siklus I dilaksanakan pada Minggu ke IV Bulan Maret. Kegiatan dilaksanakan hari Senin s.d Rabu tanggal 25 s.d 27 Maret 2013. Hasil pelaksanaan tindakan diperoleh data dari empat tahapan yang digunakan dalam penelitian tindakan kelas yang dilaksanakan.

Pada tahap perencanaan ini peneliti bekerjasama dengan pengelola dan pendidik Kelompok Matahari 2 menyusun tindakan yang dilaksanakan dengan membuat perencanaan pembelajaran yang berisi tujuan, materi, metode, media dan evaluasi pembelajaran. Perencanaan pembelajaran dilakukan terlebih dahulu sebelum pelaksanaan tindakan yang dituangkan secara tertulis dalam bentuk Rencana Kegiatan Harian (RKH) yang dapat dilihat dalam Lampiran 1 penelitian ini. Peneliti juga bekerja sama dengan pengelola dan pendidik dalam mempersiapkan kegiatan pembelajaran menggunakan media pembelajaran berbasis alam untuk mengembangkan kognitif anak usia dini beserta seting kelasnya.
Penggunaan media pembelajaran berbasis alam disiapkan peneliti dan pendidik kelompok Matahari 2 agar proses pembelajaran dalam mengembangkan kognitif anak usia dini lebih menarik, kreatif dan menyenangkan. Media yang digunakan pada siklus I ini adalah tanaman yang berada di sekitar PAUD Pandan Wangi, yaitu tanaman pandan, daun bayam, dan tanaman lain di sekitar lingkungan Pandan Wangi. Rencana pembelajaran menggunakan tema yang sedang diterapkan pada minggu itu yaitu lingkungan sekolah, dengan sub tema tanaman yang ada di lingkungan sekolah.

Indikator tingkat pencapaian perkembangan kognitif anak yang harus dicapai dalam pembelajaran penggunaan media pembelajaran berbasis alam dengan tema lingkungan sekolah dan subtema tanaman yang ada di lingkungan sekolah pada pelaksanaan siklus I, yaitu: (a) Anak dapat menunjukkan aktivitas yang bersifat eksploratif dan menyelidik, (b) Anak dapat mengenal sebab akibat tentang lingkungannya (akibat jika tanaman tidak disiram, dan daun bergerak ketika tertiup angin), (c) Anak dapat menunjukkan inisiatif dalam memilih tema permainan (bermain peran seperti pohon (tumbuh, layu, tertiup angin), (d) Anak dapat mengenal perbedaan berdasarkan ukuran :"lebih dari", "kurang dari", dan "paling/ ter", (e) Anak dapat mengklasifikasikan benda berdasarkan warna, bentuk, dan ukuran, (f) Anak dapat mengenal pola $\mathrm{ABCD}-\mathrm{ABCD}$, (g) Anak dapat mengurutkan benda berdasarkan ukuran dari paling kecil ke paling besar atau sebaliknya, (h) Anak dapat menyebutkan lambang bilangan 1-10 (menggunakan daun dan ranting).

Pada pelaksanaan siklus I, penggunaan media pembelajaran berbasis alam dilaksanakan pendidik Kelompok Matahari 2 sesuai dengan perencanaan yang telah ditetapkan pada Rencana Kegiatan Harian (RKH) dan skenario pembelajaran. Pelaksanaan tindakan dilakukan secara kolaboratif antara pendidik Kelompok Matahari 2 dengan peneliti yang bertindak sebagai observer atau pengamat, yang mengamati langsung dan merekam proses kegiatan penggunaan media pembelajaran berbasis alam yang dilakukan oleh pendidik dan 
berbagai respon yang timbul dari anak. Pelaksanaan siklus I ini dilaksanakan pada minggu IV Bulan Maret dengan 3 x pertemuan (tanggal 25 s.d 27 Maret 2013) dengan alokasi waktu pembelajaran 150 menit dimulai dari kegiatan awal, kegiatan inti dan penutup.

Pengamatan atau observasi dilakukan oleh peneliti pada saat penggunaan media pembelajaran berbasis alam berlangsung. Pada tahap ini, peneliti mengamati langsung proses kegiatan yang dilakukan oleh pendidik dan berbagai respon yang timbul dari anak melalui pedoman observasi dan catatan lapangan.

Pada siklus I ini, kemampuan kognitif anak mengalami peningkatan, walaupun target penelitian belum tercapai, hal itu belum tercapai hal ini ditunjukkan dengan perkembangan kemampuan kognitif anak sesuai dengan indikator yang ditetapkan belum semuanya berkembang optimal. Masih ada dua anak yang masih mempunyai kategori kemampuan kognitif mulai berkembang (MB).

Pada kegiatan siklus I yang dilakukan telah sesuai dengan rencana yang dibuat atau telah sesuai dengan $\mathrm{RKH}$, tetapi masih dijumpai kekurangan-kekurangan dalam pencapaian indikator tingkat perkembangan kognitif tertentu. Meskipun secara garis besar anak-anak sudah mampu melewati tahapan perkembangan kognitif sesuai indikator yang ditetapkan dengan baik.

Berdasarkan hasil observasi pada tiap indikator, diketahui kekurangan ketercapaian hasil pengembangan kemampuan kognitif anak terletak pada indikator menunjukkan aktivitas yang bersifat eksploratif dan menyelidik, indikator inisiatif dalam memilih tema permainan dan indikator mengenal pola $A B C D-A B C D$. Berikut ini adalah grafik pengembangan kemampuan kognitif anak sesuai dengan indikator yang ditetapkan melalui penggunaan media pembelajaran berbasis alam pada siklus I.

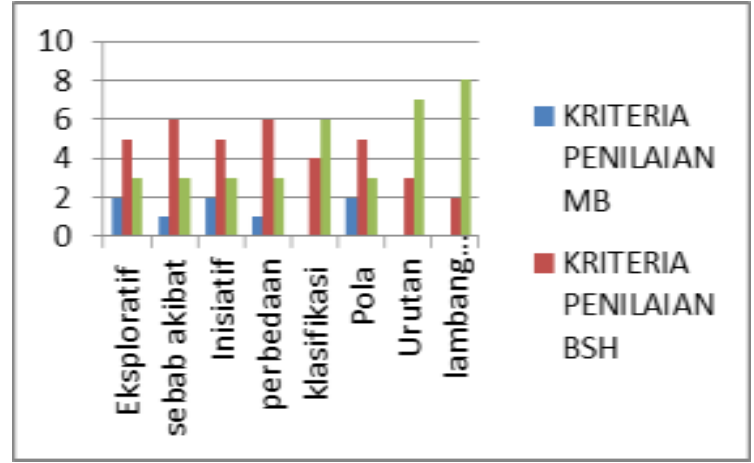

Gambar 2. Perkembangan Kemampuan

Kognitif Anak Melalui Penggunaan Media

Pembelajaran Berbasis Alam Siklus I

Berdasarkan gambar 2 indikator kemampuan kognitif anak dengan penggunaan media pembelajaran berbasis alam dapat dikatakan berkembang cukup baik adalah indikator anak dapat mengurutkan benda berdasarkan ukuran dari paling kecil ke paling besar atau sebaliknya, dan indikator anak dapat menyebutkan lambang bilangan 1-10. Hal ini dapat dilihat bahwa tidak ada anak yang mempunyai kategori kemampuan kognitif mulai berkembang (MB) pada dua indikator tersebut. Indikator yang dapat dikatakan berkembang paling baik adalah indikator anak dapat menyebutkan lambang bilangan 1-10, dimana pada indikator tersebut ada 8 anak yang mempunyai kategori kemampuan kognitif berkembang sangat baik (BSB).

Pada siklus I ini, secara umum kemampuan kognitif anak berkembang, hal ini dapat dilihat dari kemampuan anak dengan kategori mulai berkembang (MB) hanya berjumlah 2 orang yang tadinya berjumlah 4 orang sebelum tindakan, kategori Berkembang Sesuai Harapan (BSH) ada yang berjumlah $2-6$ orang pada indikator tertentu, meningkat dari kemampuan awal anak yang berjumlah rata -rata tiap indikator 6 orang, dan kategori Berkembang Sangat Baik (BSB) berjumlah $3-7$ orang yang tadinya belum ada. Dari data tersebut tampak ada pengembangan kemampuan kognitif anak apabila dibandingkan dengan data kemampuan kognitif anak sebelum penggunaan media pembelajaran berbasis alam.

Penggunaan media pembelajaran berbasis alam pada siklus I ini dirasakan dapat menjadi daya tarik bagi anak dan menim- 
bulkan antusias anak dalam mengembangkan kognitif mereka, meskipun masih terdapat kekurangan-kekurangan sehingga hasil yang diperoleh belum tercapai secara optimal. Kekurangan-kekurangan yang ditemukan dalam siklus I ini antara lain: pendidik dalam menjelaskan tema dan aturan main dalam pembelajaran yang akan dilaksanakan kurang jelas, sehingga masih ada beberapa anak yang bingung dengan apa yang harus mereka lakukan ; pendidik masih perlu meningkatkan kreativitas menggunakan media pembelajaran berbasis alam, sehingga apabila diterapkan dalam tema yang lain pendidik tidak kesulitan memodifikasi media berbasis alam tersebut.

Hasil refleksi dan rencana perbaikan tindakan tersebut sebagai acuan untuk memperbaiki hasil pada siklus II, sehingga hasil yang dicapai lebih maksimal. Perbaikan-perbaikan tersebut diharapkan dapat mengembangkan kemampuan kognitif anak sesuai indikator yang dianggap belum optimal pada siklus II. Selain itu, diharapkan semua kemampuan kognitif anak sesuai tahapan perkembangannya dapat tercapai optimal. Dengan demikian, hasil penelitian yang ditargetkan dapat tercapai secara optimal.

\section{Hasil Penelitian Siklus II}

Kegiatan penggunaan media pembelajaran berbasis alam pada siklus II dilakukan untuk mengetahui pengembangan kemampuan kognitif anak setelah mengikuti proses pembelajaran pada siklus I. Pembelajaran yang dilaksanakan menggunakan media pembelajaran berbasis alam pada siklus II ini lebih difokuskan pada indikator yang belum tercapai optimal pada pelaksanaan siklus I, meskipun ketercapaian secara optimal semua indikator tetap menjadi tujuan pelaksanaan siklus II.

Siklus II dilaksanakan pada hari Senin s.d Rabu tanggal 13 s.d 15 Mei 2013. Pelaksanaan siklus II sesuai dengan RKH dan skenario yang telah dibuat berdasarkan refleksi siklus I dalam penggunaan media pembelajaran berbasis alam. Perencanaan pembelajaran dilakukan kembali untuk memperbaiki kekurangan pada siklus I sebelum pelaksanaan tindakan siklus II yang dituangkan secara tertulis dalam bentuk Rencana Kegiatan Harian (RKH) agar hasilnya lebih baik dari siklus I. Perencanaan pembelajaran ini perlu memperhatikan kekurangan yang terjadi pada siklus I yang telah direfleksi bersama antara pendidik, pengelola dan peneliti.

Rencana pembelajaran siklus II menggunakan tema yang sedang diterapkan pada minggu itu yaitu pekerjaan, dengan sub tema macam-macam pekerjaan (tentara, petani, pelukis). Kegiatan pembelajaran pada siklus II tetap menggunakan media pembelajaran berbasis alam dengan persiapan yang lebih baik berdasarkan pengalaman pada siklus I. Pada siklus II ini media pembelajaran berbasis alam disiapkan peneliti dan pendidik kelompok Matahari 2 lebih bervariasi agar proses pembelajaran untuk mengembangkan kognitif anak lebih menarik, kreatif dan menyenangkan. Media yang digunakan pada siklus II ini antara lain pelepah pisang, daun-daun, tanah, pasir, lumpur, kerikil yang berada di sekitar PAUD Pandan Wangi.

Setelah melaksanakan kegiatan pembelajaran siklus II, peneliti bersama pendidik melakukan refleksi untuk mengetahui sejauhmana keberhasilan pembelajaran menggunakan media berbasis alam. Refleksi dilakukan berdasarkan hasil observasi terhadap aktivitas anak selama pembelajaran melalui penggunaan media pembelajaran berbasis alam yang berlangsung dalam 3 kali proses pembelajaran yang dilaksanakan.

Hasil refleksi dari siklus II yaitu terlihat adanya peningkatan yang telah dilakukan pendidik untuk memperbaiki kekurangan pembelajaran penggunaan media berbasis alam pada siklus I. Pada siklus II ini, kemampuan kognitif anak mengalami perkembangan sesuai tahapan perkembangan yang diinginkan berdasarkan indikator yang ditetapkan

Berikut ini adalah grafik perkembangan kemampuan kognitif anak sesuai dengan indikator yang ditetapkan melalui penggunaan media pembelajaran berbasis alam pada siklus II. 


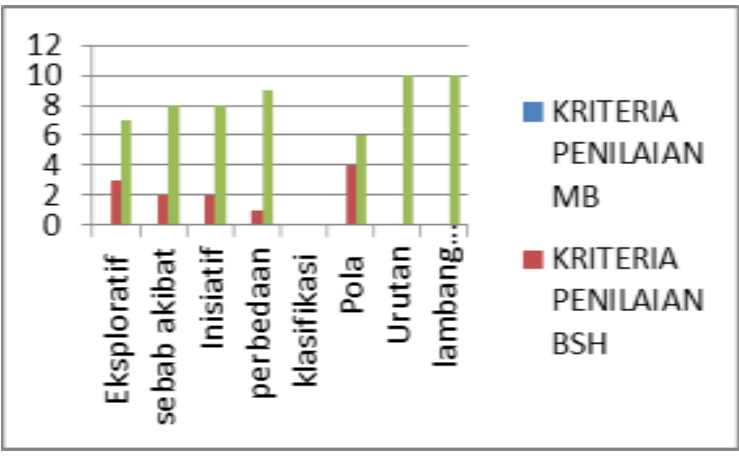

Gambar 3.Perkembangan Kemampuan Kognitif Anak Melalui Penggunaan Media Pembelajaran Berbasis Alam Siklus II.

Berdasarkan gambar 3, indikator kemampuan kemampuan kognitif anak dengan penggunaan media pembelajaran berbasis alam dapat dikatakan berkembang baik. Setiap indikator yang hendak dicapai dalam proses pembelajaran menggunakan media berbasis alam ini mengalami peningkatan tingkat ketercapaian. Indikator yang pada siklus I tingkat ketercapaiannya belum optimal, pada siklus II ini terlihat mengalami peningkatan, pada tabel diatas terlihat tidak ada lagi anak yang mempunyai tingkat ketercapaian kemampuan kognitif mulai berkembang (MB).

Dari data tersebut tampak ada peningkatan kemampuan kognitif anak yang paling tinggi terlihat peningkatannya adalah indikator anak dapat menunjukkan inisiatif dalam bermain peran. Pada siklusi I jumlah anak yang mempunyai kategori MB masih 2 orang, BSH ada 5 orang dan BSB ada 3 orang.

Pada siklus II terjadi peningkatan yang tinggi yaitu sudah tidak ada anak yang mempunyai kategori $\mathrm{MB}$, jumlah anak yang mempunyai kategori $\mathrm{BSH}$ ada 2 orang dan 8 anak sudah mempunyai kemampuan kognitif kategori BSB. Berdasarkan data tersebut terlihat peningkatan kategori kemampuan kognitif anak yang tinggi.

Hasil refleksi peneliti pendidik setelah pelaksanaan siklus II dapat dikatakan berhasil sesuai dengan target peneliti, dimana indikator-indikator yang telah ditentukan dalam pelaksanaan pembelajaran menggunakan media pembelajaran berbasis alam dapat tercapai optimal, sehingga peneliti dan pendidik menganggap sudah cukup dan tidak perlu lagi melanjutkan lagi tindakan berikutnya.

Berdasarkan hasil paparan tersebut dapat disimpulkan bahwa dalam pelaksanaan pembelajaran menggunakan media pembelajaran berbasis alam pada masingmasing indikator mengalami peningkatan, sehingga dapat dikatakan bahwa penggunaan media pembelajaran berbasis alam dalam pembelajaran untuk mengembangkan kognitif anak yang dilakukan telah berhasil.

Dampak Penggunaan Media Pembelajaran Berbasis Alam pada Kemampuan Kognitif Anak

Berdasarkan hasil observasi yang telah dilakukan terlihat dampak penggunaan media pembelajaran berbasis alam dengan adanya perkembangan kemampuan kognitif anak dalam setiap tindakan yang dilakukan pada siklus I dan siklus II. Dampak penggunaan media pembelajaran berbasis alam secara nyata terlihat dengan membandingkan hasil setiap indikator kemampuan kognitif anak yang mencapai kategori berkembang sesuai harapan (BSH) dan berkembang sangat baik (BSB) oleh anak pada saat observasi awal dengan hasil yang dicapai anak pada siklus I dan siklus II.

Dampak peningkatan kemampuan kognitif anak tidak hanya terjadi pada setiap indikator yang ditetapkan, tetapi terlihat setiap anak kelompok Matahari 2 juga mengalami perkembangan kemampuan kognitif yang berbeda-beda setelah pelaksanaan pembelajaran menggunakan media berbasis alam.

Berikut ini peneliti sajikan grafik yang menggambarkan perbandingan hasil perkembangan kemampuan kognitif anak dari observasi awal sampai pada akhir pelaksanaan tindakan (siklus I sampai siklus II). 


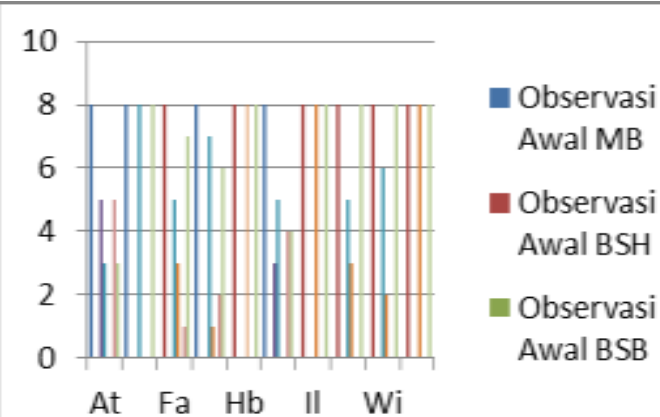

Gambar 4. Peningkatan Kemampuan Kognitif Anak Melalui Penggunaan Media Pembelajaran Berbasis Alam

Berdasarkan gambar 4 tampak bahwa ada tiga orang anak ( $\mathrm{Hb}$, Il dan $\mathrm{Zi}$ ) yang mempunyai peningkatan kemampuan kognitif yang tinggi atau cepat dalam setiap indikator yang ditetapkan dilihat dari jumlah indikator yang dapat mereka capai pada siklus I dengan kategori berkembang sangat baik (BSB) ada delapan indikator. Pada awal observasi $\mathrm{Hb}$, Il dan $\mathrm{Zi}$ menguasai delapan indikator dengan kategori berkembang sesuai harapan (BSH) kemudian pada siklus I mengalami perkembangan menguasai delapan indikator dengan kategori berkembang sangat baik, sehingga pada siklus II kemampuan kognitif mereka semakin terlihat nyata sesuai dengan perkembangan kognitif yang diharapkan. Hal itu menunjukkan bahwa $\mathrm{Hb}$, Il dan $\mathrm{Zi}$ mempunyai daya pikir yang bagus, mudah mengerti dan memahami materi yang disampaikan pendidik dan mereka memang terlihat selalu aktif dalam mengikuti pembelajaran. Kemampuan kognitif $\mathrm{Hb}$, Il dan $\mathrm{Zi}$ perlu terus dikembangkan agar kemampuan yang mereka miliki lebih terasah lagi.

\section{Pembahasan}

Penelitian tindakan kelas yang dilakukan bertujuan untuk memecahkan permasalahan yang dihadapi dalam pembelajaran terutama pengembangan kemampuan kognitif anak. Permasalahan yang dihadapi merupakan masalah yang mempunyai karakteristik khusus, dengan penelitian tindakan kelas dilakukan untuk meningkatkan kualitas pembelajaran.

Pembahasan berdasarkan tindakan kelas yang dilaksanakan tersebut berkenaan dengan kondisi awal kemampuan kognitif anak, persepsi pendidik tentang penggunaan media pembelajaran berbasis alam dalam mengembangkan kognitif anak, penggunaan media pembelajaran berbasis alam dalam mengembangkan kemampuan kognitif anak, dan dampak atau perubahan kemampuan kognitif anak yang terjadi dengan diterapkan tindakan penggunaan media pembelajaran berbasis alam di Kelompok Matahari 2 PAUD Pandan Wangi Secang Magelang yang telah dilakukan.

Kemampuan Kognitif Anak Sebelum Penggunaan Media Pembelajaran Berbasis Alam.

Penggunaan media pembelajaran berbasis alam perlu dilaksanakan dalam pembelajaran di pendidikan usai dini. Media pembelajaran berbasis alam dapat mendukung kegiatan pembelajaran untuk membantu mendekatkan jarak pemahaman kognitif anak tentang suatu konsep dan kegiatan yang dipelajari, sehingga tidak ada jarak pemahaman antara anak dan pendidik dalam proses pembelajaran. Pendidik dapat menggunakan media pembelajaran berbasis alam ini sebagai sumber belajar dengan mengajak anak dalam suasana sesungguhnya melalui belajar pada lingkungan alam sekitar yang nyata.

Untuk dapat mendukung proses pembelajaran yang dilaksanakan, pendidik harus menciptakan lingkungan belajar yang kondusif dalam segala aspek bai $\mathrm{k}$ itu kondusif secara emosional, biologis dan psikologis dalam pelaksanaan pembelajaran berbasis alam dengan media alam secara nyata tersebut. Lingkungan alam yang kondusif ini akan memudahkan anak untuk mengikuti proses pembelajaran. Hal yang dapat dilakukan untuk membuat lingkungan belajar yang kondusif secara emosional adalah memastikan anak mendengar, kondusif secara biologis adalah adanya tanaman yang bisa digunakan sebagai lingkungan belajar dan kondusif secara psikologis adalah adanya warna, estetika dan aroma dalam proses pembelajaran. Selain itu lingkungan belajar yang kondusif secara fisik juga harus diciptakan dengan kecukupan akses dengan sumber belajar. 
Kemampuan kognitif pada anak kelompok Matahari 2 PAUD Pandan Wangi sebelum diterapkan media pembelajaran berbasis alam kurang berkembang optimal. Hal ini tampak dari sebagian anak yang masih mempunyai kemampuan kognitif kategori mulai muncul, yang berarti kemampuan kognitif anak mulai berkembang, tetapi dalam melakukan kegiatan pembelajaran masih banyak dibantu pendidik.

Melihat kondisi tersebut, ada beberapa faktor yang menyebabkan hal itu terjadi antara lain yaitu pendidik belum memanfaatkan lingkungan alam sekitar secara optimal dalam proses pembelajaran, pengembangan kognitif anak lebih banyak dilakukan di ruangan dengan media buatan pabrik, anak lebih banyak dihadapkan pada sesuatu yang tidak nyata. Anak-anak harus belajar berdasarkan sesuatu yang realita, artinya anak dapat mempelajari sesuatu secara nyata dan diharapkan nantinya terjadi perubahan-perubahan perilaku berupa kemampuan-kemampuan dalam hal pengetahuan, sikap dan keterampilannya atau terjadi perubahan kemampuan kognitifnya. Hal tersebut sesuai dengan pendapat Piaget yang memandang kognitif sebagai suatu proses dimana anak secara aktif membangun sistem dan pemahaman realitas melalui pengalaman-pengalaman dan interaksi-interaksi mereka. Piaget menyebarluaskan gagasan bahwa pengetahuan diciptakan di saat anak-anak berinteraksi dengan lingkungan sosial dan lingkungan alam sekitar mereka.

Penggunaan media pembelajaran berbasis alam di PAUD harus dilaksanakan dengan metode yang tepat. Metode pembelajaran yang digunakan harus dipilih berdasarkan karakteristik tujuan dan karakteristik anak disesuaikan juga dengan media yang digunakan dalam penerapan metode tersebut. Dalam penggunaan media pembelajaran berbasis alam untuk mengembangkan kognitif anak, dapat dipergunakan metodemetode yang mampu menggerakkan anak agar menumbuhkan berpikir, menalar, mampu menarik kesimpulan, dan membuat generalisasi. Caranya adalah dengan memahami lingkungan sekitarnya, mengenal orang dan benda-benda yang ada, mema- hami tubuh dan perasaan mereka sendiri, melatih memahami untuk mengurus diri sendiri.

Pelaksanaan Penggunaan Media Pembelajaran Berbasis Alam.

Pelaksanaan penggunaan media pembelajaran berbasis alam dilakukan oleh peneliti dan pendidik dengan terlebih dahulu membuat perencanaan pembelajaran yang dituangkan dalam bentuk Rencana Kegiatan Harian (RKH). Perencanaan pembelajaran dalam RKH untuk mengembangkan kemampuan kognitif anak tidak dibuat terpisah, melainkan terintegrasi dengan lingkungan perkembangan lainnya (nilai-nilai agama dan moral, motorik, bahasa, sosialemosional).

Perencanaan dibuat agar tujuan pembelajaran dapat tercapai secara optimal. Dalam penggunaan media pembelajaran berbasis alam ini bertujuan untuk memperbaiki kualitas pembelajaran, oleh karena itu perlu dilakukan perencanaan yang baik. Untuk memperbaiki kualitas pembelajaran perlu diawali dengan perencanaan pembelajaran yang diwujudkan dengan adanya desain pembelajaran.

Tahap awal perencanaan yang dilakukan dalam penggunaan media pembelajaran berbasis alam di PAUD Pandan Wangi ini adalah menentukan tema pembelajaran, menentukan indikator kemampuan kognitif yang ingin dicapai, menentukan bahan alam apa yang akan digunakan sebagai media pembelajaran sesuai tema, materi dan strategi yang digunakan. Penentuan bahan alam yang dapat dijadikan media pembelajaran sesuai tema ini dilakukan dengan mengidentifikasi bahan alam apa saja yang tersedia dan berada di lingkungan PAUD Pandan Wangi, sehingga diharapkan media yang digunakan mudah diperoleh dan dekat dengan lingkungan anak.

Pelaksanaan penggunaan media pembelajaran berbasis alam ini dilakukan dengan menggunakan metode tanya jawab, demonstrasi, bermain peran, pemberian tugas yang dikemas dalam proses pembelajaran menggunakan media pembelajaran berbasis alam. Metode-metode tersebut dilakukan dengan mempertimbangkan ka- 
rakteristik anak dan tujuan yang akan dicapai. Orang atau siapa yang belajar dan kemampuan atau pengetahuan apa yang hendak dikuasai merupakan pertimbangan pertama. Setelah itu bagaimana catatan membelajarkan dan pada tingkat kesulitan mana kemampuan ini hendak dituntutkan diformulasikan ke dalam program-program pembelajarannya.

Tujuan utama dari penggunaan media pembelajaran berbasis alam adalah menghadapkan para siswa kepada lingkungan yang aktual untuk dipelajari, diamati dalam hubungannya dengan proses belajar mengajar. Anak dihadapkan dengan peristiwa dan keadaan yang sebenarnya secara alami, sehingga lebih nyata, lebih faktual dan kebenarannya lebih dapat dipertanggungjawabkan.

Dampak Penggunaan Media Pembelajaran Berbasis alam pada Kemampuan Kognitif Anak.

Penggunaan media pembelajaran berbasis alam memberikan dampak yang sangat baik bagi pengembangan kemampuan kognitif anak. Hal ini didasarkan pada hasil penelitian dan observasi kemampuan kognitif anak dari tindakan siklus I (Tema: Lingkungan Sekolah, Sub Tema: Tanaman yang ada di Lingkungan Sekolah) dan siklus II (Tema: Pekerjaan, Sub Tema: Macammacam Pekerjaan) menunjukkan perkembangan yang bagus sesuai dengan indikator yang ditetapkan.

Kemampuan anak dalam menunjukkan aktivitas yang bersifat eksploratif dan menyelidik, mengenal sebab akibat tentang lingkungannya, menunjukkan inisiatif dalam memilih tema permainan, mengenal perbedaan berdasarkan ukuran :"lebih dari", "kurang dari", dan "paling/ter", mengklasifikasikan benda berdasarkan warna, bentuk, dan ukuran, mengenal pola $A B C D-A B C D$, mengurutkan benda berdasarkan ukuran, dan menyebutkan lambang bilangan 1-10, menjadi lebih bagus dibandingkan dengan hasil yang dicapai ketika kegiatan pembelajaran yang dilaksanakan belum menggunakan media pembelajaran berbasis alam.

Hasil pembelajaran tersebut menunjukkan bahwa pembelajaran dengan meng- gunakan media pembelajaran berbasis alam dapat mengembangkan kemampuan kognitif anak. Penggunaan media pembelajaran berbasis alam tersebut tentunya harus sesuai dengan tujuan pembelajaran yang hendak dicapai dan harus mempertimbangkan karakteristik anak itu sendiri, dimana tahapan perkembangan anak usia 5-6 tahun berada pada tahapan pra operasional. Anak sudah mengenal simbol-simbol yang digunakan, dan sudah menyakini apa yang dilihatnya dan terfokus pada hal yang menarik bagi dirinya, namun mereka belum sadar mengenai prinsip-prinsip yang mendasarinya. Karakteristik anak pada tahap ini yaitu pemusatan perhatian pada satu dimensi dan mengesampingkan dimensi lainnya.

Kemampuan perseptual kognitif anak pada tahapan 4-6 tahun antara lain: menunjukkan minat dalam rasa dan perbedaan aktivitas sensori motor (warna, ukuran atau bentuk, suara, rasa bau, berat); menunjukkan peningkatan minat dalam angka-angka sederhana dan kuantitas kegiatan; melakukan kegiatan yang lebih bertujuan dan mampu merencanakan suatu kegiatan aktif; menunjukkan peningkatan kewaspadaan terhadap sesuatu yang nyata dalam berbagai macam bentuk, pakaian, bermain peran dan permainan konstruksi; menunjukkan minat terhadap alam, pengetahuan, binatang, waktu dan bagaimana benda bekerja.

Berdasarkan hal tersebut penggunaan media pembelajaran berbasis alam untuk mengembangkan kemampuan kognitif anak merupakan hal yang baik untuk dilakukan, karena hasil yang diperoleh berdasarkan teori dan penelitian dapat mengembangkan kemampuan kognitif anak sesuai tahapan perkembangannya. Pembelajaran yang dilaksanakan menjadi lebih menarik, karena dengan menggunakan media alam tersebut anak merasa sedang bermain bukan sedang belajar. Anak-anak bermain dengan bahan alam yang ada di sekitarnya, dalam bermain itu anak-anak tidak merasa bahwa ia sedang belajar dengan lingkungannya. Kegiatan bermain dapat membantu anak mengenal diri sendiri dengan siapa ia hidup serta lingkungan tempat di mana ia hidup.

Penggunaan media pembelajaran berbasis alam yang dilakukan pada kelompok 
Matahari 2 PAUD Pandan Wangi Secang Magelang terlihat dapat mengembangkan kemampuan kognitif anak sehingga kemampuan kognitif anak menjadi lebih baik dan dapat mencapai indikator yang ditetapkan.

\section{PENUTUP}

\section{Simpulan}

Kemampuan kognitif pada anak kelompok Matahari 2 sebelum penggunaan media pembelajaran berbasis alam masih dalam kategori belum optimal. Penggunaan media pembelajaran berbasis alam dilaksanakan sesuai dengan Rencana Kegiatan Harian $(\mathrm{RKH})$ yang disusun berdasarkan tema, pada siklus II mengalami hasil yang lebih baik daripada siklus I. anak, membimbing dan mengevaluasi anak. Anak menjadi lebih aktif dan senang melaksanakan kegiatan pembelajaran,

Penggunaan media pembelajaran berbasis alam mempunyai dampak yang sangat baik. Hal ini ditunjukkan dengan hasil penelitian bahwa kemampuan kognitif anak kelompok Matahari 2 mengalami perkembangan yang sangat baik dibandingkan sebelum tindakan. Terdapat perkembangan pencapaian kemampuan anak pada setiap indikator yang ditetapkan untuk setiap siklusnya, terutama pada siklus II.

Kemampuan kognitif anak usia 5-6 tahun yang belum mencapai tingkat pencapaian perkembangan sesuai Permendiknas No 58 Tahun 2009 secara optimal dapat dikembangkan sesuai dengan tingkat pencapaian perkembangan kognitifnya dengan melakukan kegiatan pembelajaran menggunakan media pembelajaran berbasis alam. Penggunaan media pembelajaran berbasis alam perlu diterapkan pada kelompok dan lembaga PAUD yang lain dengan memanfaatkan alam dan lingkungan sekitar sebagai media pembelajaran anak usia dini.

Penggunaan media pembelajaran berbasis alam untuk perkembangan kemampuan anak secara menyeluruh sesuai dengan tingkat pencapaian perkembangan semua aspek, baik itu perkembangan kemampuan kognitif, moral, sosial dan psikomotorik

\section{Saran}

Pengelola PAUD hendaknya dapat memfasilitasi pembelajaran menggunakan media berbasis alam dengan menyediakan sumber informasi yang memadai, sarana dan prasarana yang lengkap, media yang sesuai untuk mendukung pelaksanaan pembelajaran yang optimal sesuai dengan kebutuhan dan karakteristik pembelajaran anak usia dini sehingga anak dapat merasa nyaman dan menyenangkan ketika belajar di sekolah.

Metode dan media yang digunakan dalam pembelajaran di PAUD hendaknya sesuai dengan tema, tujuan pembelajaran, materi dan aspek perkembangan anak yang ingin dicapai.

\section{DAFTAR PUSTAKA}

Arifin, Z. (2011). Penelitian pendidikan. Metode dan paradigma baru. Bandung: Remaja Rosdakarya

Arsyad, A. (2011). Media pembelajaran. Jakarta: Rajawali Pers.

Barnett, W. (1995). Long term effect of early childhood programs on cognitive and school outcomes. The Future of Children Long Term Outcomes Of Early Childhood Programs Vol 5. No 3.

Depdiknas. (2008). Model Pembelajaran Berbasis Alam Pendidikan Anak Usia Dini Formal dan Nonformal. Diambil pada tanggal 4 Mei 2012, darihttp://www.scribd.com/doc/33 666826/Model-PAUD-Berbasis-

Alam.

Galotti, K. (2004). Cognitive psychology. in and out of the laboratory. Wadsworth: a division of Thompson Learning, Inc

Hergenhahn, BR \& Olson, MH (1997). An introduction to theories of learning. $\left(5^{\text {th }}\right.$ ed). New Jersey: Prentice-Hall, Inc

Kemendikbud. (2009). Peraturan Menteri Pendidikan Nasional No 58 tahun 
2009, Tentang Standar Pengelolaan PAUD.

Morrison, G. S. (2012). Dasar-dasar pendidikan anak usia dini $\left(5^{\text {th }}\right.$ ed). (Terjemahan Suci Romadhona \& Apri Widiastuti). New Jersey: Pearson Education, Inc. (Buku asli diterbitkan Tahun 2008).

Nielsen, D. M (2008). Mengelola kelas untuk guru TK. (Terjemahan Febrianti Ika Dewi). San Diego: A Sage Publica- tions Company. (Buku Asli diterbitkan Tahun 2006).

Segal, M. et al. (2012). All about child care and early dducation. ( $\left.2^{\text {nd }} e d\right)$. New Jersey: Pearson.

Sujiono, Y.N (2009). Konsep dasar pendidikan anak usia dini. Jakarta: PT indeks

Republik Indonesia. (2003). Undang-Undang RI Nomor 20, Tahun 2003, tentang Sistem Pendidikan Nasional. 